\title{
S17 - Conocimiento de la atención del paro cardiorrespiratorio en médicos del Hospital Pedro de Bethancourt
}

\author{
Henrry Samayoa $^{1 *}$, Rosa J. Chiroy ${ }^{2}$, Alfredo Menegazzo $^{2}$ \\ ${ }^{1}$ Hospital Pedro de Bethancourt, Antigua Guatemala; ${ }^{2}$ Liga Guatemalteca del Corazón, Guatemala.
}

*Autor al que se dirige la correspondencia: medintantigua@gmail.com

\section{Resumen}

- 1 paro cardiorrespiratorio (PCR) es el cese de la respiración y el latido cardiaco en una persona. Las maniobras de reanimación cardiopulmonar (RCP) son el conjunto de maniobras que se realizan con la finalidad de sustituir y restaurar la circulación y respiración espontánea en un paciente en PCR. El objetivo fue evaluar el conocimiento de la atención del PCR según Guías AHA 2010 en los médicos que laboran durante el año 2014 en el Hospital Pedro de Bethancourt de la Antigua Guatemala. Se realizó un estudio descriptivo comparativo. Para evaluar el conocimiento de la atención del PCR entre los médicos jefes (especialistas) y médicos residentes, se utilizó un cuestionario de 30 preguntas sobre conocimientos de soporte vital básico y avanzado. Se logró la participación de 104 médicos. El promedio de calificación fue de 33 puntos para los Médicos Jefes y de 23 puntos para los Médicos Residentes. Los médicos que laboran en el Hospital Pedro de Bethancourt no tienen el conocimiento óptimo de la atención del PCR avanzado según las Guías de la AHA 2010.

Palabras claves:

\begin{abstract}
$\mathrm{T}$ he cardiorespiratory arrest (CRA) is the cessation of breathing and heartbeat in a person. The cardiopulmonary resuscitation (CPR) are the set of operations performed in order to replace and restore circulation and spontaneous breathing in a patient in cardiac arrest. The aim of this study was to evaluate the knowledge of cardiopulmonary resuscitation based on 2010 AHA Guidelines among physicians in 2014 at Hospital Pedro de Bethancourt in Antigua Guatemala. A descriptive comparative study was conducted. To assess knowledge of CRA attention among head doctors (specialists) and resident physicians, a questionnaire of 30 questions about knowledge of basic and advanced life support was used. A total of 104 physicians were recruited. The average score was 33 points for the head doctors and 23 points for the resident physicians. Physicians at Hospital Pedro de Bethancourt do not have the appropriate knowledge of CPR based on 2010 AHA Guidelines.
\end{abstract}

Keywords: 